\title{
Fertilization in vitro of rat oocytes undergoing maturation in response to a $\mathrm{GnRH}$ analogue
}

\author{
N. Dekel and R. Shalgi* \\ Department of Hormone Research, The Weizmann Institute of Science, Rehovot 76100, and \\ * Department of Embryology and Teratology, Tel Aviv University School of Medicine, Tel Aviv, \\ Israel
}

\begin{abstract}
Summary. Oocytes were exposed to GnRHa to induce their maturation both in vivo, by administration of the hormone to hypophysectomized rats, and in vitro, in cultures of intact ovarian follicles. Mature oocytes obtained under both these conditions were then exposed in vitro to a sperm suspension for fertilization. Fertilization of control groups of oocytes, isolated from intact or hypophysectomized PMSG-primed hCG-induced ovulators, was $88 \cdot 3 \pm 3 \cdot 3 \%(n=331)$ and $90 \cdot 0 \pm 2 \cdot 8 \%(n=427)$, respectively, as compared to $82 \cdot 8 \pm 3 \cdot 2 \%(n=413)$ for oocytes isolated from hypophysectomized PMSG-primed GnRHa-induced ovulators. Fertilization rate in oocytes treated by GnRHa in vitro was $78 \cdot 5 \pm 3 \cdot 1 \%(n=247)$ as compared to $79 \cdot 3 \pm 4 \cdot 1 \%(n=261)$ in LH-treated oocytes. These results demonstrate that fertilizability of oocytes undergoing maturation in response to $\mathrm{GnRHa}$ is similar to that of oocytes induced to mature by LH. No differences could be detected in the proportions of abnormal oocytes (polyspermic, fragmented and dead) and the zygotes obtained after fertilization of GnRHa- or LH-treated oocytes showed similar ability to cleave.
\end{abstract}

\section{Introduction}

Until fairly recently it was generally accepted that the pituitary, which is stimulated by gonadotrophinreleasing hormone (GnRH) to synthesize and secrete gonadotrophins, is the only target for this hormone. However, later experiments have shown that $\mathrm{GnRH}$ and its agonist analogues can also elicit ovarian responses in vitro, in isolated ovarian cells (Clayton et al., 1979; Hsueh \& Erickson, 1979; Labrie et al., 1979; Behrman et al., 1980; Clark et al., 1980; Hsueh \& Jones, 1981; Knecht et al., 1983) and in vivo in hypophysectomized rats (Ying \& Guillemin, 1979; Hsueh et al., 1980; Corbin \& Bex, 1981; Ekholm et al., 1981; Dekel et al., 1983, 1985; Erickson et al., 1983; Naor et al., 1983). These findings, together with the demonstration of ovarian receptors for GnRH (Clayton et al., 1979; Jones et al., 1980; Clayton \& Catt, 1981; Seguin et al., 1982), suggested that GnRH can interact with the ovary in a direct manner.

It is known that the follicular oocyte in mammals is arrested at the diplotene stage of prophase of the first meiotic division (Austin, 1961) and that the physiological stimulus for resumption of meiosis is provided by the preovulatory surge of luteinizing hormone (LH) (Ayalon et al., 1972). The observation that GnRH could mimic $\mathrm{LH}$ action, inducing meiosis resumption, was initially reported by Hillensjö \& LeMaire (1980), who found that exposure of isolated ovarian follicles to GnRH or its agonist analogues in vitro results in maturation of the oocytes. The direct stimulatory action of GnRH on the ovary has also been demonstrated in vivo. Both oocyte maturation and ovulation were induced in hypophysectomized rats after administration of GnRH agonists (Hsueh \& Erickson, 1979; Corbin \& Bex, 1981; Ekholm et al., 1981; Dekel et al., 1983, 1985; Erickson et al., 1983; Naor et al., 1983).

The studies discussed above demonstrated that $\mathrm{GnRH}$, like $\mathrm{LH}$, can stimulate the oocyte to 
mature, and can trigger the follicle to release the mature oocyte. LH action results in the release of a functional fertilizable oocyte; after sperm penetration this oocyte will develop into a normal embryo. Neither fertilization nor normal development, however, have yet been demonstrated following stimulation by GnRH. On the contrary, it has been reported that a significant fraction of degenerated oocytes is present in ovaries of GnRH-treated rats (Hsueh et al., 1980; Erikson et al., 1983; Naor et al., 1983), indicating that the developmental ability of these oocytes may be impaired. The diagnosis of GnRH-induced oocyte maturation is based only on morphological markers such as germinal vesicle breakdown or polar body formation (Hillensjö \& LeMaire, 1980; Ekholm et al., 1981; Dekel et al., 1983, 1985). Our study was designed to assess the ability of oocytes undergoing maturation in response to $\mathrm{GnRH}$ to be fertilized.

\section{Materials and Methods}

Hormones. The GnRH agonist analogue [D-Ser(t-Bu) ${ }^{6}$ ]des-Gly ${ }^{10}-\mathrm{GnRH}-\mathrm{N}$-ethylamide (GnRHa), used in this study was purchased from Hoechst AG (Frankfurt, West Germany). To study the effect of LH in vitro NIH-LH-S20 was added to the culture medium. For hormonal preparation of the rats, PMSG (Gestyl: Organon, Oss, The Netherlands) and hCG (Pregnyl: Organon) were used.

Oocyte maturation and ovulation in vivo. We have characterized the induction of oocyte maturation and ovulation by GnRHa in hypophysectomized rats of our departmental colony (Dekel et al., 1985). This rat model was used in the present study as the source for oocytes undergoing maturation in response to GnRHa in vivo. Briefly, 25-day-old rats were injected with PMSG (15 i.u./rat) immediately after hypophysectomy and with GnRHa ( $2 \mu \mathrm{g} / \mathrm{rat})$ or hCG (4 i.u./ rat) $48 \mathrm{~h}$ later. The rats were killed by $20 \mathrm{~h}$ after hormone administration. The ovulated oocytes were recovered from the oviducts and transferred to a sperm cell suspension for in-vitro fertilization.

Maturation of oocytes in vitro. Oocytes matured in vitro in response to GnRHa were obtained by the use of a follicle-enclosed oocyte culture system. The effect of both GnRHa and LH on oocytes in this system has previously been studied by us (Dekel et al., 1983). Briefly, follicles were isolated from 27-day-old rats, $48 \mathrm{~h}$ after PMSG (15 i.u./rat) administration. The isolated follicles were transferred to L-15 Leibovitz tissue culture medium (Gibco, NY, U.S.A.) supplemented with $10 \%$ fetal bovine serum (Sera-Lab, Crawley Down, U.K.) and antibiotics (100 U penicillin $/ \mathrm{ml}, 50 \mu \mathrm{g}$ streptomycin/ml: Sigma, St Louis, MO, U.S.A.) and incubated in a shaking water bath at $37^{\circ} \mathrm{C}$ in an atmosphere of $\mathrm{O}_{2}: \mathrm{N}_{2}(1: 1 \mathrm{v} / \mathrm{v})$ in the absence or the presence of GnRHa $\left(10^{-7} \mathrm{M}\right)$ or $\mathrm{LH}(5 \mu \mathrm{g} / \mathrm{ml})$. Oocytes recovered from the follicles at $18 \mathrm{~h}$ after exposure to the hormones were transferred to a sperm suspension for in-vitro fertilization.

Fertilization in vitro. Spermatozoa were collected from the uteri of mature cyclic rats soon after mating (Shalgi et al., 1981) and the sperm concentration was adjusted to $4-7 \times 10^{5} / \mathrm{ml}$ by dilution with Rat Fertilization Medium (Kaplan \& Kraicer, 1978). Samples of sperm suspension $(200 \mu \mathrm{l})$ were incubated under heavy paraffin oil at $37^{\circ} \mathrm{C}$ in an atmosphere of $5 \% \mathrm{CO}_{2}$ in air. The oocytes were introduced to the sperm suspension (10-15 per sample) after $3 \mathrm{~h}$ of sperm incubation. The ova were examined by Nomarski interference-contrast microscopy for fertilization and first cleavage after $24 \mathrm{~h}$. Ova were considered fertilized when a sperm flagellum was seen in the vitellus (Shalgi \& Phillips, 1982). The numbers of fragmented, dead and polyspermic oocytes were also recorded. The fraction of oocytes under each category was calculated. All data were tested using $\chi^{2}$ distribution tests. Significance was defined as $P<0 \cdot 05$.

A control group of oocytes (isolated from the oviducts of 28-day-old, intact PMSG/hCG-treated rats) was included for each experiment. This control group was used to standardize the results according to daily variations in fertilization rates which may result from the use of different donors of spermatozoa (Shalgi et al., 1981).

\section{Results}

Fertilization rate of the control groups of oocytes isolated from intact or hypophysectomized PMSG-primed, hCG-induced ovulators was $88 \cdot 3 \pm 3 \cdot 3 \%(n=331)$ and $90 \cdot 0 \pm 2 \cdot 8 \%(n=427)$ respectively. The success rate of fertilization of oocytes undergoing maturation and ovulation in vivo in response to GnRHa was not significantly different $(82 \cdot 8 \pm 3 \cdot 2, n=413)$. Fertilization rate of oocytes exposed to GnRHa in vitro was lower than that of control oocytes, isolated from the oviducts of intact PMSG/hCG-treated rats $(78 \cdot 5 \pm 3 \cdot 1, n=247$, compared to $91 \cdot 7 \pm 2 \cdot 4, n=$ 379 ), but did not differ significantly from that of oocytes exposed in vitro to LH $(79 \cdot 3 \pm 4 \cdot 1, n=$ $261 P>0 \cdot 1)$. The extent of fragmentation and death was also significantly higher in the oocytes exposed to hormones in vitro $(P<0.01)$, with no differences between the two hormonal treatments $(P>0 \cdot 1)$ (Table 1$)$. 
Table 1. Numbers of fertilized oocytes with polyspermia, in-ggmented or dead oocytes, and 2-cell embryos after incubation for $24 \mathrm{~h}$ with spe matozoa

\begin{tabular}{|c|c|c|c|c|c|c|}
\hline & \multicolumn{2}{|c|}{ Fragmented/dead oocytes } & \multicolumn{2}{|c|}{ Polyspermic oocytes } & \multicolumn{2}{|c|}{ 2-Cell embryos } \\
\hline & $\begin{array}{l}\text { Matured } \\
\text { in vivo } \\
(\%)^{*}\end{array}$ & $\begin{array}{l}\text { Matured } \\
\text { in vitro } \\
(\%)^{*}\end{array}$ & $\begin{array}{c}\text { Matured } \\
\text { in vivo } \\
(\%) \dagger\end{array}$ & $\begin{array}{c}\text { Matured } \\
\text { in vitro } \\
(\%) \dagger\end{array}$ & $\begin{array}{c}\text { Matured } \\
\text { in vivo } \\
(\%) \dagger\end{array}$ & $\begin{array}{c}\text { Matured } \\
\text { iii vitro } \\
(\%) \dagger\end{array}$ \\
\hline Control & $0 / 331(0)$ & $32 / 379 \quad(8.4)$ & $48 / 289(16 \cdot 6)$ & $65 / 351(18 \cdot 5)$ & $115 / 289(39 \cdot 8)$ & $135 / 351(38 \cdot 5)$ \\
\hline GnRHa & $39 / 413(9 \cdot 4)$ & $44 / 247(17 \cdot 8)$ & $38 / 330(11 \cdot 5)$ & $58 / 199(29 \cdot 1)$ & $138 / 330(41 \cdot 8)$ & $16 / 199(0 \cdot 8)$ \\
\hline $\mathrm{LH} / \mathrm{hCG}$ & $29 / 427(6 \cdot 7)$ & $45 / 261(17 \cdot 3)$ & $68 / 374(18 \cdot 2)$ & $65 / 208(31 \cdot 2)$ & $201 / 374(53 \cdot 7)$ & $5 / 208 \quad(0.02)$ \\
\hline No hormone & - & $3 / 187(1 \cdot 6)$ & - & 1/ $15(6 \cdot 0)$ & - & $0 / 15(0)$ \\
\hline
\end{tabular}

*Of total oocytes incubated with spermatozoa.

†Of fertilized oocytes.

Some of the oocytes diagnosed as fertilized were penetrated by more than one spermatozoon cell. No significant differences in the rate of polyspermic oocytes was observed between the two hormonal treatments $(P>0 \cdot 1)$ (Table 1$)$. However, polyspermia was significantly more prominent in the oocytes exposed to both hormones in vitro than in oocytes exposed to the hormones in vivo $(P<0.01)$.

The reduced ability of the fertilized oocytes undergoing maturation in vitro to develop was clearly manifested by the stage of the first cleavage. While about $50 \%$ of the oocytes undergoing maturation in vivo in response to hCG or GnRHa had the potential to cleave after fertilization, almost none of the oocytes matured in vitro proceeded to the 2-cell stage embryo (Table 1).

\section{Discussion}

Gur preseni siudy demonstrates that the potential of oocytes undergoing maturation in response to GnRHa stimulation to be fertilized is similar to that of oocytes stimulated by $\mathrm{LH} / \mathrm{hCG}$. Moreover, their ability to develop further into a 2-cell embryo is also similar. The exploration of the mode of the direct action of GnRHa on the oocyte is of immediate clinical importance. GnRH was initially used to treat infertile women with gonadotrophin deficiency. Since hypothalamic GnRH is known to control the secretion of gonadotrophins by the pituitary, it is believed that GnRH treatment activates the pituitary-gonadal axis to induce follicular development and ovulation. However, since it is clear that, at least in the rat, GnRH acts on extrapituitary targets as well (for review see Hsueh \& Jones, 1981), the direct interaction of GnRH with the ovary should be taken into consideration. Moreover, treatment with GnRH agonists is not limited to infertile patients. Massive doses of this hormone are administered daily to young girls with idiopathic precocious puberty (Yen, 1983). GnRH exerts its action on large as well as small antral follicles (N. Dekel, unpublished). As a significant fraction of oocytes at terminal stages of degeneration can be oiserved in the ovaries of GnRH-treated rats (Hsueh et al., 1980; Erikson et al., 1983; Ranta et al., 198:) and as chronic treatment with GnRH stimulates excessive recruitment of oocytes followed by their thassive degeneration (Naor et al., 1983), there could be a possible clinical hazard using this therapy.

The stildies on GnRH, discussed above, have all been performed in the rat, and an important question is whether such findings can be extended to other species. Attempts to answer this question by investigating whether ovarian GnRH receptors are present has yielded negative results for wom 'n (Clayton \& Huhtaniemi, 1982), sheep, cattle and pigs (Brown \& Reeves, 1983). However, direct o varian effects of GnRH agonists have been shown in the pig (Massicotte et al., 1980), cow (Milvae \& Hansel, 1980) and man (Tureck et al., 1982), and specific but "low affinity" 
GnRH-agonist receptors have been demonstrated in human corpus luteum (Popkin et al., 1983). It is possible that inability to demonstrate receptors for $\mathrm{GnRH}$ in ovaries of some species results from technical problems associated with such studies because, even in rat ovaries, GnRH receptors are few in number.

Our findings cannot point towards any impaired fertilizability of oocytes exposed to GnRH. Furthermore, they do indicate that oocytes undergoing maturation in response to GnRH have a potential to cleave similar to that of LH-stimulated oocytes. They cannot, however, give any indication as to the potential of these oocytes to develop beyond the 2-cell stage. The development of the embryos derived from oocytes undergoing maturation in response to GnRH is now being investigated in our laboratory. The results obtained in the present study using oocytes exposed to hormones (GnRHa as well as $\mathrm{LH}$ ) in vitro clearly indicate that this system cannot provide oocytes which have the ability to develop beyond the 2-cell stage after fertilization. For our further studies, therefore, only oocytes that have been exposed to hormones in vivo will be used.

This study was supported by grants from the Israel Academy of Science and Humanities, United States-Israel Binational Science Foundation and the Minerva Foundation Munich, West Germany. We thank Dr A. Nimrod for preparing the hypophysectomized rats used for this study; Dr B. Catz for her help in statistical analysis; Mrs D Galiani and A. Mathityahu for technical assistance; and Mrs R. Levin for secretarial assistance.

\section{References}

Austin, C.R. (1961) The Mammalian Egg. Blackwell, Oxford.

Ayalon, D., Tsafriri, A., Lindner, H.R., Cordova, T. \& Harell, A. (1972) Serum gonadotrophin levels in prooestrous rats in relation to the resumption of meiosis by the oocytes. J. Reprod. Fert. 31, 51-58.

Behrman, H.R., Preston, S.L. \& Hall, A.K. (1980) Cellular mechanism of the antigonadotropic action of luteinizing hormone-releasing hormone in the corpus luteum. Endocrinology 107, 656-664.

Brown, J.L. \& Reeves, J.J. (1983) Absence of specific LHRH receptors in ovine, bovine and porcine ovaries. Biol. Reprod. 29, 1179-1182.

Clark, M.R., Thibier, C., Marsh, J.M. \& LeMaire, W.J. (1980) Stimulation of prostaglandin accumulation by luteinizing hormone-releasing hormone (LHRH) and LHRH analogs in rat granulosa cells in vitro. Endocrinology 107, 17-23.

Clayton, R.N. \& Catt, K.J. (1981) Gonadotrophinreleasing hormone receptors: characterization, physiological regulation and relationship to reproductive function. Endocrine Rev. 2, 186-209.

Clayton, R.N. \& Huhtaniemi, I.T. (1982) Absence of gonadotrophin-releasing hormone receptors in human gonadal tissue. Nature, Lond. 299, 56-59.

Clayton, R.N., Harwood, J.P. \& Catt, K.J. (1979) Gonadotrophin-releasing hormone analogue binds to luteal cells and inhibits progesterone production. Nature, Lond. 282, 90-92.

Corbin, A. \& Bex, F.J. (1981) Luteinizing hormone releasing hormone agonists induce ovulation in hypophysectomized proestrous rats: direct ovarian effects. Life Sci. 29, 185-192.

Dekel, N., Sherizly, I., Tsafriri, A. \& Naor, Z. (1983) A comparative study of the mechanism of action of luteinizing hormone and gonadotropin releasing hormone analog on the ovary. Biol. Reprod. 28, 161-166.

Dekel, N., Sherizly, I., Phillips, D.M., Nimrod, A., Zilberstein, M. \& Naor, Z. (1985) Characterization of the maturational changes induced by a $\mathrm{GnRH}$ analogue in the rat ovarian follicle. J. Reprod. Fert. 75, 461466.

Ekholm, C., Hillensjö, T. \& Isaksson, O. (1981) Gonadotropin-releasing hormone agonists stimulate oocyte meiosis and ovulation in hypophysectomized rats. Endocrinology 108, 2022-2024.

Erickson, G.F., Hofeditz, C. \& Hsueh, A.J.W. (1983) GnRH stimulates meiotic maturation in preantral follicles of hypophysectomized rats. In Factors Regulating Ovarian Function, pp. 257-261. Eds G. S. Greenwald \& P. F. Terranova. Raven Press, New York.

Hillensjö, T. \& LeMaire, W.J. (1980) Gonadotrophin releasing hormone agonists stimulate meiotic maturation of follicle-enclosed rat oocytes in vitro. Nature, Lond. 287, 145-146.

Hsueh, A.J.W. \& Erickson, G.F. (1979) Extrapituitary action of gonadotrophin-releasing hormone: direct inhibition of ovarian steroidogenesis. Science, N.Y. 204, 854-855.

Hsueh, A.J.W. \& Jones, P.B.C. (1981) Extrajituitary action of gonadotropin-releasing-hormore. Endocrine Rev. 2, 437-461.

Hsueh, A.J.W., Wang, C. \& Erickson, G.F. (1980) Direct inhibitory effect of gonadotropin-re!casing hormone upon follicle-stimulating hormone induction of luteinizing hormone receptor and aroratase activity in rat granulosa cells. Endocrinology 106, 1697-1705.

Jones, P.B.C., Conn, P.M., Marian, J. \& Hsueh, A.J.W. 
(1980) Binding of gonadotrophin-releasing hormone agonist to rat ovarian granulosa cells. Life $S$ ci. 27, 2125-2132.

Kaplan, R. \& Kraicer, P.F. (1978) Effect of elevated calcium concentration on fertilization of rat oocytes in vitro. Gamete Res. 1, 281-285.

Knecht, M., Ranta, T., Naor, Z. \& Catt, K.J. (1983) Direct effects of GnRH in the ovary. In Factors Regulating Ovarian Function, pp. 225-243. Eds G. S. Greenwald \& P. F. Terranova. Raven Press, New York.

Labrie, F., Auclair, C., Cusan, L., Lamay, A., Belanger, A., Kelly, P.A., Ferland, F., Azadian-Boulanger, G. \& Raynaud, J.-P. (1979) Inhibitory effects of treatment with LHRH or its agonists on ovarian receptor levels and function. In Ovarian Follicular and Corpus Luteum Function, pp. 687-701. Eds C. P. Channing, J. M. Marsh \& W. A. Sadler. Plenum Press, New York.

Massicotte, J., Veilleux, R., Lavoie, M. \& Labrie, F. (1980) An LHRH agonist inhibits FSH-induced cyclic AMP accumulation and steroidogenesis in porcine granulosa cells in culture. Biochem. Biophys. Res. Commun. 94, 1362-1366.

Milvae, R. \& Hansel, W. (1980) A luteolytic effect of GnRH on bovine luteal cells in vitro. J. Anim. Sci. 51 (Suppl. 1), 306, Abstr. 484.

Naor, Z., Zilberstein, M., Zakut, H., Lindner, H.R. \& Dekel, N. (1983) Dissociation between the direct stimulatory and inhibitory effects of a gonadotrophin releasing hormone analogue on ovarian function. Molec. cell. Endocr. 31, 261-270.
Popkin, R.M., Bramley, T.A., Currie, A.J., Shaw, R.W., Baird, D.T. \& Fraser, H.M. (1983) Specific binding of luteinizing hormone-releasing hormone to human luteal tissue. Biochem. Biophys. Res. Commun. 114, $750-756$.

Ranta, T., Baukal, A., Knecht, M.K., Korhonen, M. \& Catt, K.J. (1983) Inhibitory action of a gondatropinreleasing hormone agonist on ovarian folliclestimulating hormone receptors and adenylate cyclase in vivo. Endocrinology 112, 956-964.

Seguin, C., Pelletier, G., Dube, D. \& Labrie, F. (1982) Distribution of luteinizing hormone-releasing hormone receptors in the rat ovary. Regulatory Peptides 4, 183-190.

Shalgi, R. \& Phillips, D.M. (1982) Sperm penetration into rat ova fertilized in vitro. $J$. Androl. 3, 382-387.

Shalgi, R., Kaplan, R., Nebel, L. \& Kraicer, P.F. (1981) The male factor in fertilization of rat eggs in vitro. $J$. exp. Zool. 217, 399-402.

Tureck, R.W., Mastorianni, L., Blasco, L., Jr. \& Strauss, J.R. (1982) Inhibition of human granulosa cells progesterone secretion by a gonadotropin releasing hormone agonist. J. clin. Endocr. Metab. 54, 10781080 .

Yen, S.S.C. (1983) Clinical applications of gonadotropinreleasing hormone and gonadotropin-releasing hormone analogs. Fert. Steril. 39, 257-266.

Ying, S.Y. \& Guillemin, R. (1979) (D-Trp ${ }^{6} \cdot$ Pro $\left.^{9}-N E t\right)-$ luteinizing hormone releasing factor inhibits follicular development in hypophysectomized rats. Nature, Lond. 280, 593-595. 